Scientific article

Volumen 32(2):399-421. Mayo-agosto, 2021

e-ISSN 2215-3608, doi:10.15517/am.v32i2.43281

https://www.revistas.ucr.ac.cr/index.php/agromeso

\title{
High population density in arracacha (Arracacia xanthorrhiza Bancroft) increase radiation interception, yield, and profitability ${ }^{1}$
}

\section{Densidad poblacional alta en arracacha (Arracacia xanthorrhiza Bancroft) aumenta la intercepción de la radiación, el rendimiento y la rentabilidad}

\author{
Yeison Mauricio Quevedo-Amaya ${ }^{2}$,Jorge Enrique Villamil-Carvajal ${ }^{2}$, Johanna Paola Garnica-Montaña ${ }^{2}$, \\ Omar Montenegro-Ramos ${ }^{2}$,Eduardo Barragán-Quijano²
}

1 Reception: August $3^{\text {rd }}, 2020$. Acceptance: December $14^{\text {th }}, 2020$. This study is a part of the Project "Integrated crop management focused on soils, water and weed control for the production of arracacha in Colombia" included in the macro project "Generation and use of genetic materials, integrated crop management, postharvest and transformation of arracacha in the Andean region of Colombia."

2 Corporacion Colombiana de Investigacion Agropecuaria (AGROSAVIA). Km 9 Via El Espinal- Chicoral, Tolima - Colombia. Zip Code 733529. yquevedoa@unal.edu.co (Corresponding author, https://orcid.org/0000-0001-5352-931X), jvillamil@agrosavia.co (https://orcid. org/0000-0003-0173-0921), jgarnicam@agrosavia.co (https://orcid.org/0000-0003-3051-809X), omontenegro@agrosavia.co (https://orcid. org/0000-0001-8905-5283), ebarragan@agrosavia.co (https://orcid.org/0000-0002-9260-6346).

\begin{abstract}
Introduction. Arracacha (Arracacia xanthorrhiza Bancroft) a promising crop due to its nutritional and gastronomic relevance. Population density is an agronomic practice that increases water and radiation use efficiencies, maximizes the yield, and crop profitability. However, the selection of the optimal population density based on physiological, agronomic, and economic criteria for arracacha has not been studied. Objective. To describe the effect of different population densities on the physiology, yield, and profitability of arracacha. Materials and methods. The experiment was conducted in Cajamarca, Colombia in 2019. There, the soil water potential, relative chlorophyll content, photosynthesis, stomatal conductance, water use efficiency, leaf temperature depression, photosynthetic reflectance index, leaf area index, the fraction of light interception, light extinction coefficient, cracking index, yield, and profitability were evaluated. Results. The results showed that high population densities did not generate water deficit because there were no significant differences for the soil water potential, leaf temperature depression, and photosynthetic reflectance index. Furthermore, no nutritional deficiencies were evidenced because the relative chlorophyll content ( $<32$ SPAD) was higher at the critical level. Due to this, no limitations were observed in leaf gas exchange processes. However, the densities of 25,000 and 30,000 plants ha ${ }^{-1}$ showed a higher fraction of light interception due to the increase in the leaf area index; this allowed to obtain a higher yield at these densities. Conclusion. The maximum yield $\left(41.96 \mathrm{t} \mathrm{ha}^{-1}\right)$ and profitability (US\$ $\left.15,333.06 \mathrm{ha}^{-1}\right)$ were reached with a population density of 22,222 plants ha ${ }^{-1}$.
\end{abstract}

Keywords: plant density, leaf area index, planting systems, intraspecific competition, optimization methods.

\section{Resumen}

Introducción. La arracacha (Arracacia xanthorrhiza Bancroft) es un cultivo promisorio por su relevancia nutricional y gastronómica. La densidad poblacional es una práctica agronómica que aumenta la eficiencia del uso 
del agua y la radiación, maximiza el rendimiento y la rentabilidad de los cultivos. Sin embargo, no se ha estudiado para la arracacha la selección de la densidad poblacional óptima basada en criterios fisiológicos, agronómicos y económicos. Objetivo. Describir el efecto de diferentes densidades poblacionales sobre la fisiología, el rendimiento y la rentabilidad de la arracacha. Materiales y métodos. El experimento se realizó en Cajamarca-Colombia durante el 2019. Allí se evaluó el potencial hídrico del suelo, y en arracacha el contenido relativo de clorofila, la fotosíntesis, la conductancia estomática, la eficiencia en el uso del agua, la depresión de la temperatura de la hoja, el índice de reflectancia fotosintética, el índice de área foliar, la fracción de intercepción de luz, el coeficiente de extinción de luz, el índice de agrietamiento, el rendimiento y la rentabilidad. Resultados. Los resultados mostraron que las altas densidades poblacionales no generaron déficit hídrico porque no hubo diferencias significativas en el potencial hídrico del suelo, la depresión de la temperatura foliar y el índice de reflectancia fotosintética. Además, no se evidenciaron deficiencias nutricionales porque el contenido relativo de clorofila ( $<32$ SPAD) fue mayor al nivel crítico. Debido a esto, no se observaron limitaciones en los procesos de intercambio de gases. Sin embargo, las densidades de 25000 y 30000 plantas ha-1 mostraron una mayor fracción de intercepción de luz debido al aumento del índice de área foliar; esto permitió obtener un mayor rendimiento a estas densidades. Conclusión. El máximo rendimiento $\left(41,96\right.$ t ha $\left.{ }^{-1}\right)$ y rentabilidad (US\$ $15333,06 \mathrm{ha}^{-1}$ ), se alcanzaron con una densidad poblacional de 22222 plantas ha-1.

Palabras clave: densidad de plantas, índice de área foliar, sistemas de siembra, competencia intraespecífica, optimización de métodos.

\section{Introduction}

Arracacia xanthorrhiza Bancroft is one the most promising crop among Andean roots and tubers (Rosso et al., 2002), due to its gastronomic and nutritional importance for the Andean countries (Zarate et al., 2008). It is widely planting in Brazil, Colombia, Puerto Rico, Peru, Ecuador, and Venezuela, where it is part of the diet of the population (Alvarado \& Ochoa, 2010; Morillo et al., 2020). The arracacha genotypes sowing in Colombia have yellow flesh root color (Garnica-Montaña et al., 2020; Pinto-Acero et al., 2019).

With an increasing world population, it is necessary to develop management practices that increase the yield of relevant crops such as arracacha to meet the demand for carbohydrates. Defining an optimal population density is a practice used worldwide to increase crop productivity (Sun et al., 2018), as it determines the number of established plants that are the first crop yield component. An optimal population density allows the radiation use efficiency, water, and nutrients (Hou et al., 2019). To maximize its benefits, intraspecific competition for limiting photosynthesis resources, including nutrients, water, and radiation, should be minimized (Song et al., 2020). Likewise, agronomic management practices must be supported by a higher economic benefit for farmers (Zhang et al., 2018).

For the arracacha crop, the population density has been normally selected from empirical and traditional knowledge, ignoring the physiological behavior of the plant and the relationship with economic indicators of the production system. In Brazil, the population densities used by farmers range between 20,000 and 47,600 plants ha-1 (Hermann, 1997; Morillo et al., 2020) while in Colombia, the most common practice is 20,000 plants ha-1 (Alvarado $\&$ Ochoa, 2010). The behavior of the photosynthetic apparatus of arracacha has been reported only by Jaimez et al. (2008). However, net photosynthesis and photosynthetic reflectance index (PRI) have not been studied under conditions of high population densities. Globally, studies reported the effect of population density on the yield of arracacha with populations higher than 60,000 plants ha ${ }^{-1}$ (Graciano et al., 2007; Torales-Pacito et al., 2015; Zarate et al., 2009); however, the physiological behavior of the plant under intraspecific competition conditions has not been described. 
High population densities can limit nitrogen availability and generate deficiencies due to intraspecific competition (Al-Naggar et al., 2015). The lack of nitrogen can reduce the content of chlorophyll and RuBisCO, limiting photosynthesis and the availability of carbohydrates for the part of the plant that is of economic value (Imai et al., 2008), which for arracacha are the commercial roots. The arracacha crop requires between $200-250 \mathrm{~kg}$ $\mathrm{ha}^{-1}$ of nitrogen for reach an optimal biological yield (Magolbo et al., 2015). The amount of fertilizers is increased depending on the population density to mitigate this effect, but consequently increases the cost of production. Therefore, it is necessary to identify population densities that do not generate nitrogen deficiency (Bänziger et al., 1999; Hou et al., 2019) and that are economically viable.

High population densities increase water uptake attributed to a higher amount of root tissue expressed by a higher number of plants that generate a reduction of soil water potential (Luo et al., 2011; Bermúdez-Florez et al., 2018; Honda et al., 2019). This plant water status alteration produces stomatal and non-stomatal limitations of photosynthesis (Chastain et al., 2016; Drake et al., 2017). For this reason, it is necessary to identify population densities that do not generate water deficit and do not affect crop photosynthesis (Honda et al., 2019).

The leaf area index directly influences the photosynthesis of a crop or its primary productivity since it defines the fraction of light interception (Fang \& Liang, 2008), as well as water and nutrient use efficiency (Bréda, 2008). The increase in population densities increases competition for photosynthetically active radiation (PAR) that causes a reduction in crop photosynthesis. Hence, genotypes with tolerance to a high intraspecific competition show morphological adjustments to avoid stress due to a lack of radiation. Changes in the leaf area index and the light extinction coefficient also occur (Quevedo et al., 2018; Sher et al., 2018).

The leaf area index directly influences the crop photosynthesis or its primary productivity since it defines the fraction of light interception (Fang \& Liang, 2008), as well as water and nutrient use efficiency (Bréda, 2008; Hatfield \& Dold et al., 2019). The increase in population densities increases competition for photosynthetically active radiation (PAR) that causes a reduction in crop photosynthesis. Hence, genotypes with tolerance to a high intraspecific competition show morphological adjustments to avoid stress due to lack of radiation. Changes in the leaf area index and the light extinction coefficient also occur (Quevedo et al., 2018; Sher et al., 2018).

Variables such as the amount of PAR, the efficiency in the interception and conversion of PAR and $\mathrm{CO}_{2}$ into biomass, and the efficiency in partitioning biomass to the harvestable organ determine crop yield (Slattery et al., 2017). Therefore, the establishment of the functionality of the photosynthetic apparatus at the leaf and crop levels is a tool for the identification of the optimal population density that maximizes the resources use efficiency. The PRI is related to gross primary productivity (Garbulsky et al., 2008; Kováč et al., 2018); and to non-photochemical quenching related to the xanthophyll cycle as a protection mechanism of photosystem II (PSII) (Kohzuma \& Hikosaka, 2018). Leaf temperature depression (LTD) is an indicator of stomatal conductance and is useful for detecting the degree of water deficit (Biju et al., 2018).

Because there is little knowledge of the physiological effect and the technical and economic viability of population densities in arracacha, it is necessary to elucidate the effects of various population densities on the soil water potential, the fraction of light interception, leaf gas exchange, and its relationship with yield and economic indicators. The objective of this study was to describe the effect of different population densities on the physiology, yield, and profitability of arracacha.

\section{Materials and methods}

\section{Experimental setup and agronomic management}

The study was carried out between January and December of 2019 in the municipality of Cajamarca, province of Tolima, in Colombia, at the geographic coordinates $4^{\circ} 23^{\prime} 44.4^{\prime \prime} \mathrm{N}$ and $75^{\circ} 28^{\prime} 08.5^{\prime \prime} \mathrm{W}$. The soil of the 
experimental area was an Andisol with a sandy loam dominant texture, granular structure, moderately developed, and good natural drainage (Chaali et al., 2020). Five population densities (PD) were evaluated (Table 1) in a completely randomized block design with three replicates, using a total of fifteen experimental units each with an area of $30 \mathrm{~m}^{2}$ and six rows with a length of $5 \mathrm{~m}$, using the three central rows as a useful plot. The total test area was $682 \mathrm{~m}^{2}$. The blocking factors were the slope gradient and soil chemical fertility. The arracacha genotype sown corresponds to the Agrosavia La 22 variety (Rodríguez et al., 2019).

Table 1. Population density treatments evaluated in the variety of arracacha (Arracacia xanthorrhiza Bancroft) Agrosavia La 22 variety. Cajamarca, Colombia. 2019.

Cuadro 1. Tratamientos de densidad poblacional evaluados en la variedad de arracacha (Arracacia xanthorrhiza Bancroft) Agrosavia La 22. Cajamarca, Colombia. 2019.

\begin{tabular}{|c|c|c|c|}
\hline Treatment & Furrow distance (m) & Plant spacing (m) & $\begin{array}{l}\text { Population density } \\
\quad(\text { plants ha-1) }\end{array}$ \\
\hline 1 & 1.00 & 1.00 & 10,000 \\
\hline 2 & 1.00 & 0.75 & 15,000 \\
\hline 3 & 1.00 & 0.50 & 20,000 \\
\hline 4 & 1.00 & 0.40 & 25,000 \\
\hline 5 & 1.00 & 0.33 & 30,000 \\
\hline
\end{tabular}

Agronomic management was performed equally in all PD treatments. Mineral nutrition was calculated based on the nutrient content of the soil and crop requirements (Madeira et al., 2017). The control of insect pests and diseases was carried out chemically according to the incidence and level of damage found in plants.

\section{Measurement of variables}

\section{Climate}

From 50 days after sowing (DAS) were recorded the maximum daytime and minimum night temperatures, average relative humidity, solar radiation, and accumulated daily precipitation using a Vantage Pro2 automated weather station (Davis, San Francisco, CA, USA) located at the experimental field. The vapor-pressure deficit was calculated using Eq. 1, where Ta is the maximum daytime temperature, and HR is the relative humidity in percentage (García \& Moreno, 2016).

$$
V P D=0.01078 \mathrm{e}^{\left(\frac{(17.269 * \mathrm{Ta})}{(237.3+\mathrm{Ta})}\right) *\left(1-\frac{\mathrm{HR}}{100}\right)}
$$

\section{Soil water potential}

The volumetric soil moisture ( $\theta$ ) was evaluated at 167, 220, 240, and 286 DAS at a depth between 0-10 cm on nine plants per treatment recorded with a GS3 sensor (METER Group. Inc., Pullman, WA, USA) (Son et al., 2017). The soil water potential $(\Psi \mathrm{s})$ was calculated using Eq. 2, which was obtained from the soil moisture retention curve of the experimental batch. 


$$
\Psi_{S}=0.4514+\frac{0.009}{\theta}
$$

\section{Relative chlorophyll content}

The relative chlorophyll content (RCC) was recorded at 167, 220, 240, and 286 DAS in nine plants per treatment on fully expanded leaves. A SPAD 502 chlorophyll meter (Konica Minolta, Japan) was used (Westerveld et al., 2004).

\section{Leaf gas exchange}

The light saturation point of the photosynthesis was estimated in $1,500 \mu \mathrm{mol} \mathrm{m}^{-2} \mathrm{~s}^{-1}$ (Figure 1) by elaborating a light response curve $\left(0,100,300,600,900,1,100,1,400,1,700\right.$ and $\left.2,000 \mu \mathrm{mol} \mathrm{m}^{-2} \mathrm{~s}^{-1}\right)$ on nine plants, according to Vongcharoen et al. (2018). With a photonic flux density of $1,500 \mu \mathrm{mol} \mathrm{m}^{-2} \mathrm{~s}^{-1}$ and a $\mathrm{CO}_{2}$ concentration of $400 \mu \mathrm{mol}$ $\mathrm{CO}_{2} \mathrm{~mol}^{-1}$, were assessed the following leaf gas exchange parameters: net photosynthesis (A), stomatal conductance (gs), and transpiration at 167,220,240, and 286 DAS in fully expanded leaves of nine plants per treatment (Jaimez et al., 2008). The instantaneous water use efficiency (WUEi) was calculated as the A and transpiration ratio. An LI-6400 XT open system infrared gas analyzer (Li-Cor, Lincoln, NE. USA) was used.

\section{Leaf temperature depression}

Leaf and air temperature were evaluated with a thermocouple adapted to an LI-6400 XT open system infrared gas analyzer (Li-Cor, Lincoln, NE. USA). The LTD was calculated using Eq. 3, where Tf is leaf temperature, and Ta is the air temperature (Biju et al., 2018).

$$
\mathrm{LTD}=\mathrm{Tf}-\mathrm{Ta}
$$

\section{Photosynthetic reflectance index}

Reflectance at 532 and $570 \mathrm{~nm}$ were recorded with an SRS-PRI sensor coupled to an EM-50 datalogger (METER Group. Inc., Pullman, WA, USA) between 11:00 and 12:00 hours at 286 DAS, corresponding to the end of a dry period. The photosynthetic reflectance index (PRI) was calculated employing Eq. 4 (Castro \& SanchezAzofeifa, 2018).

$$
P R I=\frac{\rho 532-\rho 570}{\rho 532+\rho 570}
$$

Where @ represents the reflectance at a specific wavelength. PRI values were expressed as the scaled PRI (sPRI) in a range of 0-1 using Eq. 5.

$$
\mathrm{sPRI}=\frac{(1+\mathrm{PRI})}{2}
$$


Leaf area index, fraction of light interception and light extinction coefficient

Leaf area index (LAI), fraction of light interception (Fi) and light extinction coefficient were evaluated at 220, 240, and 286 DAS between 11:00 and 12:00 hours with an Accupar LP-80 linear ceptometer (METER Group. Inc., Pullman, WA, USA). The leaf area index (LAI), PAR above (RS) and below the canopy (RD) was evaluated (Vahrmeijer et al., 2018). With this information, the fraction of light interception (Fi) was calculated using Eq. 6 (Shi et al., 2016), and the light extinction coefficient (k) was obtained using Eq. 7 (Flénet et al., 1996).

$$
\begin{aligned}
& \mathrm{Fi}=1-\left(\frac{\mathrm{RS}}{\mathrm{RD}}\right) \\
& \mathrm{k}=\frac{-\ln \left(\frac{\mathrm{RS}}{\mathrm{RD}}\right)}{\mathrm{LAI}}
\end{aligned}
$$

\section{Yield and cracking index}

Yield evaluation was performed at 378 DAS. Thirty plants were harvested per treatment, and the total weight of healthy commercial roots, roots with cracking during harvest, and roots with cracking in the field were recorded. With this information, the cracking index in the field (CIf) and during harvest (CIh) were calculated using Eq. 8 and Eq. 9 adapted from Hartz et al. (2005).

$$
\begin{aligned}
& C I f=\frac{\text { Weight of roots with crackings in the field }}{\text { Total weight of roots }} \\
& C I h=\frac{\text { Weight of roots with crackings during harvest }}{\text { Total weight of commercial roots }}
\end{aligned}
$$

\section{Economic analysis}

The profitability of the productive system was established using the difference between the gross profit and the production costs for each of the PDs evaluated (Page et al., 2019), using the 2018-2019 average sales prices for Colombia according to the Sistema de Informacion de Precios (SIPSA) of the Departamento Administrativo Nacional de Estadistica (2020).

\section{Statistical analysis}

The Michaelis Menten model was used for the identification of the light saturation point of photosynthesis. A third-order sigmoidal regression model was applied between yield, profitability, and PD. Data analysis was performed using generalized linear mixed models with the comparison of DGC means with a p-value of 0.05 . The PD treatments and evaluation time were used as fixed effects and the block as a random effect. The best model was selected using the Akaike criterion with Bayesian information and maximum likelihood (Jaramillo-Barrios et al., 2019). The results only 
interpreted the factors and interaction that showed significant differences and the significant individual effects when the interaction did not show significant differences. The R-studio software version 1.1.463 was used.

\section{Results}

\section{Climate behavior}

The maximum daytime temperature ranged from $18-28.7^{\circ} \mathrm{C}$ and the minimum temperature between $10-15.6{ }^{\circ} \mathrm{C}$. Between 260 and 300 DAS, no precipitation occurred; after 300 DAS, daily rainfall of up to $58.4 \mathrm{~mm}$ was recorded. During the life cycle, the accumulated precipitation was $844.6 \mathrm{~mm}$. Further, between 50-300 DAS, the daily radiation was less than 30,000 $\mathrm{Cal} \mathrm{cm}^{2} \mathrm{day}^{-1}$, and after $300 \mathrm{DAS}$, the solar radiation increased registering values of up to $56,262 \mathrm{Cal} \mathrm{cm}^{2}$ day $^{-1}$. The vapor-pressure deficit throughout the plant life cycle was less than $1.0 \mathrm{KPa}$.

\section{Soil water potential}

The soil water potential $\left(\Psi_{\mathrm{s}}\right)$ did not exhibit significant differences because of the PDs, but were observed between the evaluation times (Table 2). During the four evaluation times, the $\Psi$ s showed a low variability that ranged between -0.49 and $-0.51 \mathrm{MPa}$ (Figure 1).

Table 2. Results of the analysis of the generalized linear mixed models for the evaluated parameters in populations densities in arracacha (Arracacia xanthorrhiza Bancroft) Agrosavia La 22 variety. Cajamarca, Colombia. 2019.

Cuadro 2. Resultados del análisis de los modelos lineales mixtos generalizados para los parámetros evaluados en densidades poblacionales en arracacha (Arracacia xanthorrhiza Bancroft) variedad Agrosavia La 22. Cajamarca, Colombia. 2019.

\begin{tabular}{lccc}
\hline & & Variation source & \\
\cline { 2 - 4 } Variable & Population density & Assessment time & Population density x Time \\
\hline Soil water potential & $*$ & $\mathrm{~ns}$ & $\mathrm{~ns}$ \\
Relative chlorophyll content & $\mathrm{ns}$ & $* * *$ & $*$ \\
Net photosynthesis & $\mathrm{ns}$ & $* * *$ & $\mathrm{~ns}$ \\
Stomatal conductance & $*$ & $* * *$ & $* *$ \\
Water use efficiency & $\mathrm{ns}$ & $* * *$ & $\mathrm{~ns}$ \\
Leaf temperature depression & $\mathrm{ns}$ & $* * *$ & $* *$ \\
Photosynthetic reflectance index & $* * *$ & na & na \\
Leaf area index & $* * *$ & $* * *$ & $* * *$ \\
Fraction of light interception & $* * *$ & $* * *$ & ns \\
Light extinction coefficient & $\mathrm{ns}$ & $* * *$ & na \\
Cracking index in the field & $*$ & na & na \\
Cracking index during harvest & $*$ & na & na \\
Number of commercial roots per plant & $* *$ & na & na \\
Average length of commercial roots & $* *$ & na & na \\
Average diameter of commercial roots & $*$ & na & na \\
Average weight of commercial roots & $* * *$ & na & na \\
Commercial yield & $* * *$ & na & \\
\hline
\end{tabular}

Not significant: ns; does not apply: na; $\mathrm{p} \leq 0.05$ : *; $\mathrm{p} \leq 0.01$ : **; $\mathrm{p} \leq 0.001$ : *** / No significativo: ns; no aplica: na; $\mathrm{p} \leq 0,05: * ; \mathrm{p} \leq 0,01$ : $* * ; \mathrm{p} \leq 0,001: * * *$ 


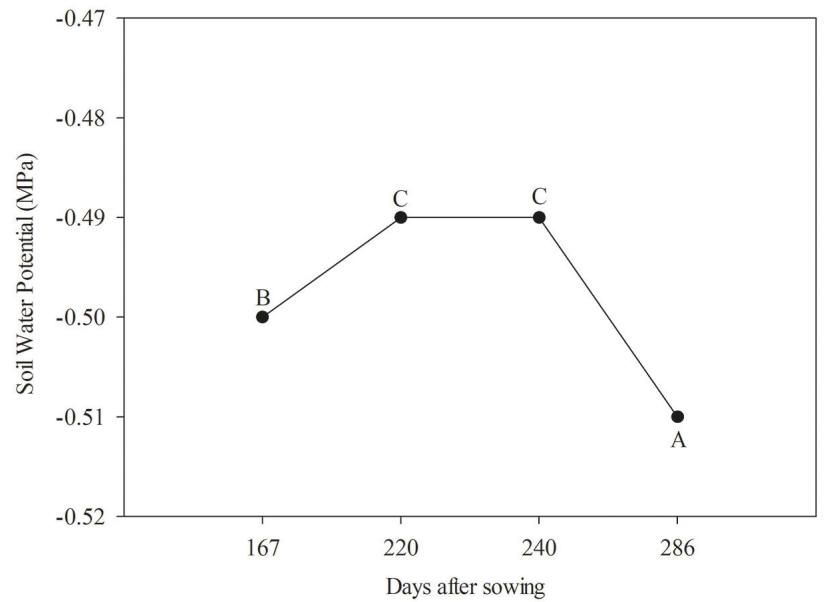

Figure 1. Soil water potential at a depth between 0-10 $\mathrm{cm}$ during four evaluation times of populations densities in arracacha (Arracacia xanthorrhiza Bancroft) Agrosavia La 22 variety. Cajamarca, Colombia. 2019.

The data shown are the means of three replicates with the standard error indicated by the vertical lines. Different letters indicate significant differences for $\mathrm{p} \leq 0.05$, according to the DGC test.

Figura 1. Potencial hídrico del suelo a una profundidad de 0-10 cm durante cuatro tiempos de evaluación de densidades poblacionales en arracacha (Arracacia xanthorrhiza Bancroft) variedad Agrosavia La 22. Cajamarca, Colombia. 2019.

Los datos mostrados son el promedio de tres repeticiones con el error estándar indicado por las líneas verticales. Diferentes letras indican diferencias significativas para $\mathrm{p} \leq 0,05$, según la prueba de DGC.

\section{Relative chlorophyll content}

The relative chlorophyll content (RCC) showed significant differences for the time-PD interaction (Table 2). A decreasing trend over time was observed for all PDs. With 20,000 plants ha ${ }^{-1}$ at 167 (40.22 SPAD) and 240 DAS (36.41 SPAD), a significantly higher RCC compared to the other PDs was found. The RCC in 220 and 286 DAS was statistically the same in all the PDs (Figure 2). The high difference between 167 and 286 DAS could be attributed to senescence or nitrogen remobilization. The high RCC found with 20,000 plants ha ${ }^{-1}$ it's an indicator of better nutritional status than the others PD.

\section{Leaf gas exchange}

The light saturation point was $1,500 \mu \mathrm{mol} \mathrm{m}^{-2} \mathrm{~s}^{-1}$, where leaf gas exchange (A) was $14.28 \mu \mathrm{mol} \mathrm{m}^{-2} \mathrm{~s}^{-1}$, and the light compensation point was $222.05 \mu \mathrm{mol} \mathrm{m}^{-2} \mathrm{~s}^{-1}$ of PAR (Figure 3). A showed highly significant differences in the time factor (Table 2). At $220 \mathrm{DAS}$, a was significantly higher $\left(24.61 \mu \mathrm{mol} \mathrm{m}^{-2} \mathrm{~s}^{-1}\right)$ compared to the other evaluation times. Between 240 DAS $\left(19.55 \mu \mathrm{mol} \mathrm{m}^{-2} \mathrm{~s}^{-1}\right)$ and 286 DAS $\left(18.25 \mu \mathrm{mol} \mathrm{m}^{-2} \mathrm{~s}^{-1}\right)$, no statistical differences were observed (Figure 4A). The gs presented significant differences in the time-PD interaction (Table 2). At 167 and 286 DAS, there were no significant differences between treatments. At 220 DAS, the treatment of 20,000 plants ha $^{-1}\left(0.76 \mathrm{~mol} \mathrm{~m}^{-2} \mathrm{~s}^{-1}\right)$ showed the highest gs, being significantly higher compared to the other PDs. At 240 DAS, the treatment of 30,000 plants ha ${ }^{-1}\left(0.79 \mathrm{~mol} \mathrm{~m}^{-2} \mathrm{~s}^{-1}\right)$ showed the highest gs with respect to the other PDs (Figure 4B). The WUEi exhibited highly significant differences for the time factor (Table 2) and was statistically different between all the evaluation times (Figure 4C). The lowest WUEi $\left(3.11 \mu \mathrm{mol} \mathrm{mol}^{-1}\right)$ was found at 240 DAS. 


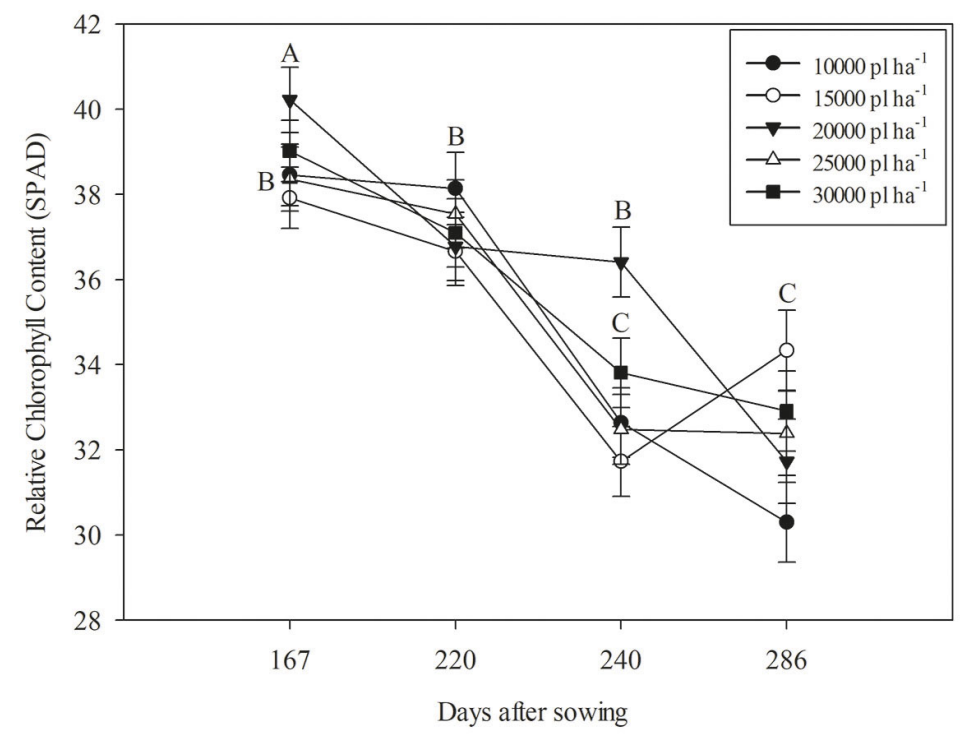

Figure 2. Relative chlorophyll content in four evaluation times for arracacha (Arracacia xanthorrhiza Bancroft) plants of the Agrosavia La 22 variety, subjected to five population densities. Cajamarca, Colombia. 2019.

The data shown are the means of three replicates with the standard error indicated by the vertical lines. Different letters indicate significant differences for $\mathrm{p} \leq 0.05$, according to the DGC test. $\mathrm{pl} \mathrm{ha}^{-1}$ : plants per hectare.

Figura 2. Contenido relativo de clorofila en cuatro tiempos de evaluación en plantas de arracacha (Arracacia xanthorrhiza Bancroft) variedad Agrosavia La 22, sometidas a cinco densidades poblacionales. Cajamarca, Colombia. 2019.

Los datos mostrados son el promedio de tres repeticiones con el error estándar indicado en las líneas verticales. Diferentes letras indican diferencias significativas para $\mathrm{p} \leq 0,05$, de acuerdo con la prueba de DGC. $\mathrm{pl} \mathrm{ha}^{-1}$ : plantas por hectárea.

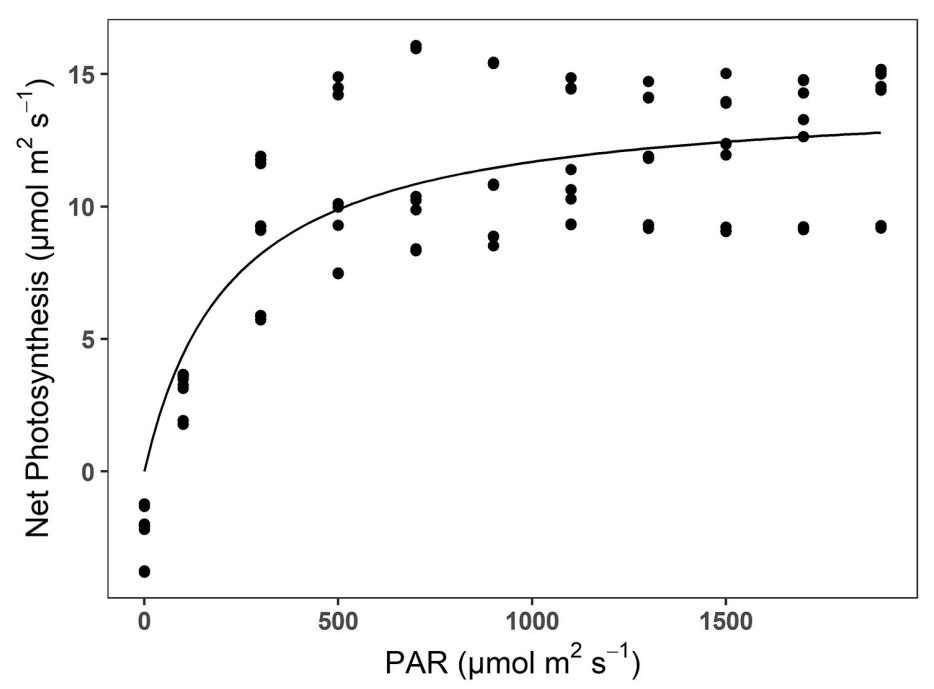

Figure 3. Michaelis Menten model for the response of photosynthesis to the photosynthetically active radiation (PAR) in arracacha (Arracacia xanthorrhiza Bancroft) plants of the Agrosavia La 22 variety. Cajamarca, Colombia. 2019.

Figura 3. Modelo Michaelis Menten para la respuesta de la fotosíntesis a la radiación fotosintética activa (PAR) en plantas de arracacha (Arracacia xanthorrhiza Bancroft) variedad Agrosavia La 22. Cajamarca, Colombia. 2019. 

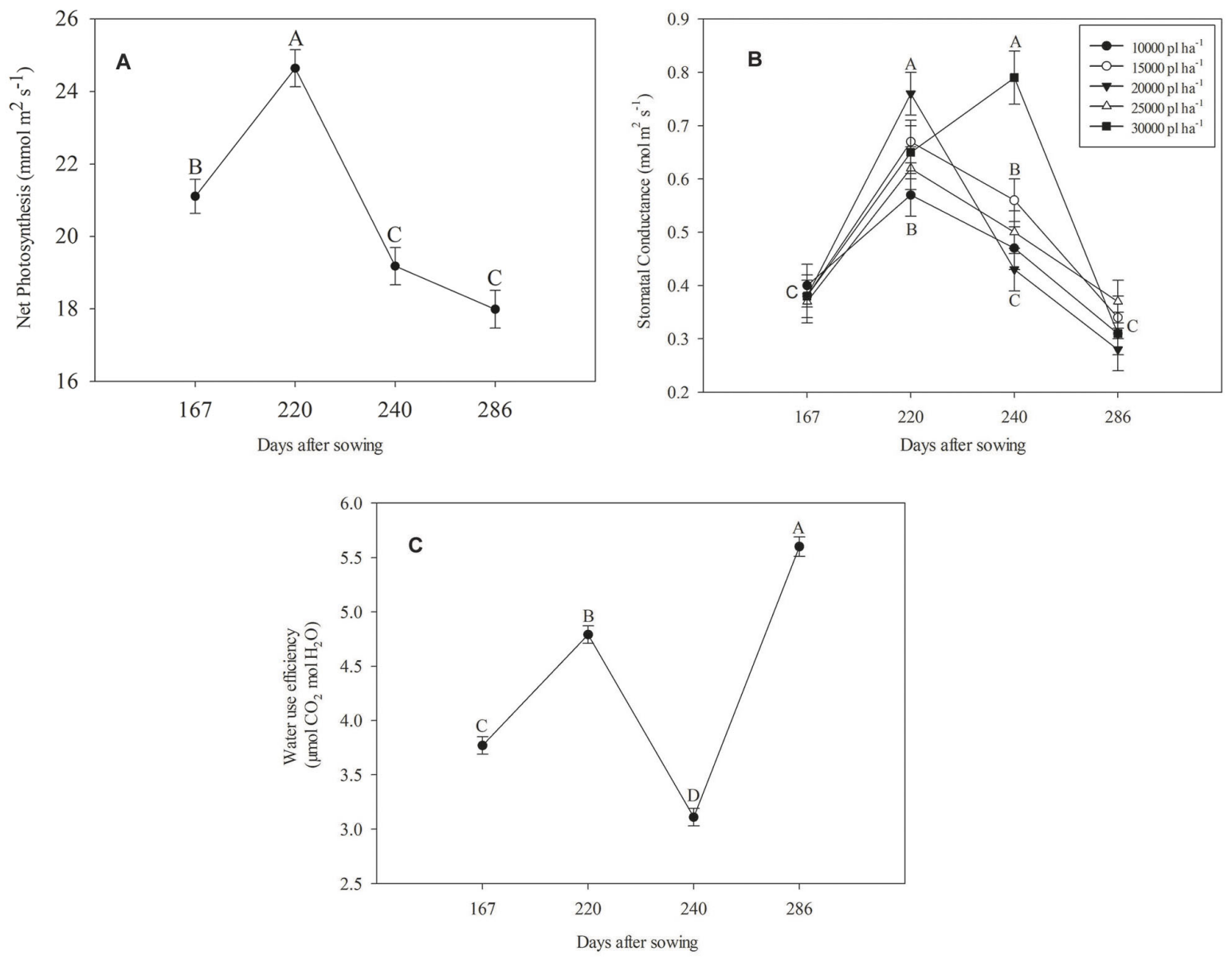

Figure 4. Leaf gas exchange variables for arracacha (Arracacia xanthorrhiza Bancroft) plants of the Agrosavia La 22 variety, subjected to five population densities in four evaluation times. Cajamarca, Colombia. 2019. A. Net photosynthesis, B. Stomatal conductance, and C. Instantaneous water use efficiency.

The data shown are the means of three replicates with the standard error indicated by the vertical lines. Different letters indicate significant differences for $\mathrm{p} \leq 0.05$, according to the DGC test. $\mathrm{pl} \mathrm{ha}^{-1}$ : plants per hectare.

Figura 4. Variables de intercambio de gases de la hoja para plantas de arracacha (Arracacia xanthorrhiza Bancroft) de la variedad Agrosavia La 22, sometidas a cinco densidades poblacionales en cuatro tiempos de evaluación. Cajamarca, Colombia. 2019. A. Fotosíntesis neta, B. Conductancia estomática, y C. Eficiencia instantánea en el uso del agua.

Los datos mostrados son el promedio de tres repeticiones con el error estándar indicado por las líneas verticales. Diferentes letras indican diferencias significativas para $\mathrm{p} \leq 0,05$, según la prueba de la DGC. $\mathrm{pl} \mathrm{ha}^{-1}$ : plantas por hectárea.

\section{Leaf temperature depression and photosynthetic reflectance index}

The leaf temperature depression (LTD) showed significant differences in the time-PD interaction (Table 2). Between 167-240 DAS, the LTD was $<0$, and no statistical differences were observed between the treatments. The treatment of 30,000 plants ha-1 at 240 DAS showed the lowest LTD $\left(-1.3^{\circ} \mathrm{C}\right)$, being statistically different from the other PDs. At 286 DAS, all the treatments showed a LTD $>0$ (Figure 5A). The photosynthetic reflectante index 

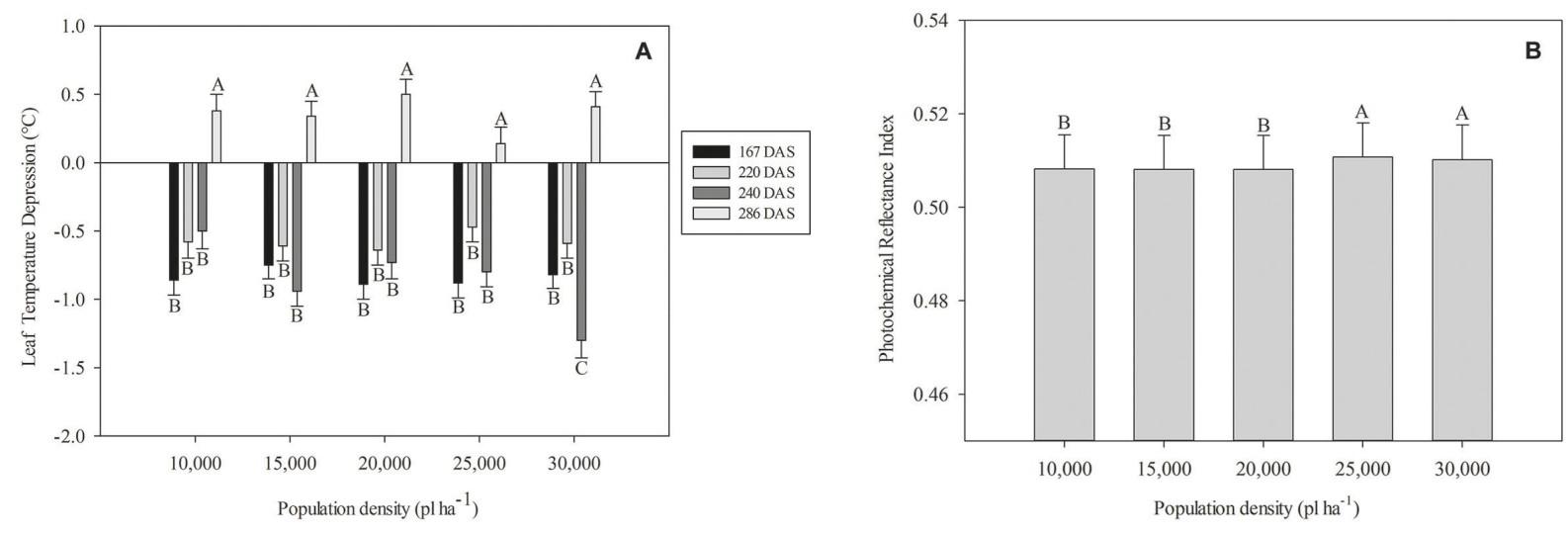

Figure 5. A. Leaf temperature depression in four evaluation times for arracacha (Arracacia xanthorrhiza Bancroft) plants of the Agrosavia La 22 variety, subjected to five population densities. Cajamarca-Colombia. 2019, and B. Photosynthetic reflectance index for arracacha (Arracacia xanthorrhiza Bancroft) plants of the Agrosavia La 22 variety, subjected to four population densities. Cajamarca, Colombia. 2019.

The data shown are the means of three replicates with the standard error indicated by the vertical lines. Different letters indicate significant differences for $\mathrm{p} \leq 0.05$, according to the DGC test. $\mathrm{pl} \mathrm{ha}^{-1}$ : plants per hectare.

Figura 5. A. Depresión de la temperatura de la hoja en cuatro tiempos de evaluación para plantas de arracacha (Arracacia xanthorrhiza Bancroft) de la variedad Agrosavia La 22, sometidas a cinco densidades poblacionales. Cajamarca, Colombia 2019, y B. Índice de reflectancia fotosintética para las plantas de arracacha (Arracacia xanthorrhiza Bancroft) variedad Agrosavia La 22, sometidas a cuatro densidades poblacionales. Cajamarca-Colombia 2019.

Los datos mostrados son el promedio de tres repeticiones con el error estándar indicado por las líneas verticales. Diferentes letras indican diferencias significativas para $\mathrm{p} \leq 0,05$, según la prueba de la DGC. $\mathrm{pl} \mathrm{ha}{ }^{-1}$ : plantas por hectárea.

(PRI) showed highly significant differences between PDs (Table 2). The PDs of 10,000, 15,000, and 20,000 plants ha $^{-1}$ were statistically equal (Figure 5B). On the other hand, the PDs of 25,000 and 30,000 plants ha ${ }^{-1}$ did not show statistical differences, and their PRI (0.51) was significantly higher than the PDs of 10,000, 15,000, and 20,000 plants ha-1.

\section{Leaf area index, fraction of light interception, and extinction coefficient}

The leaf area index (LAI) showed highly significant differences in the interaction time-PD (Table 2). The LAI at 220 DAS showed an increasing trend as the PD increased, while the PDs of 20,000, 25,000, and 30,000 plants $\mathrm{ha}^{-1}$ had statistically equal LAI (2.90-3.02). At 240 DAS, the PDs of 30,000 and 25,000 plants ha-1 showed values of 3.69 and 2.9, respectively, for LAI, being statistically higher than the other PDs (Figure 6A). At 286 DAS, the LAI was statistically equal between the PDs, ranging from 1.62 to 1.27 . The behavior of fraction of light interception (Fi) (Figure 6B) was similar to the one observed in LAI (Figure 7A). The highest Fi was found at 220 DAS (0.87$0.9)$ and 240 DAS (0.85-0.89) in the PDs of 25,000 and 30,000 plants ha ${ }^{-1}$. The light extinction coefficient (k) showed highly significant differences by effect of the evaluation time (Table 2). Further, a decreasing trend was observed over time in the k (Figure 6C); at 220 DAS, the k was 0.78 , being significantly higher than the other evaluation times. 

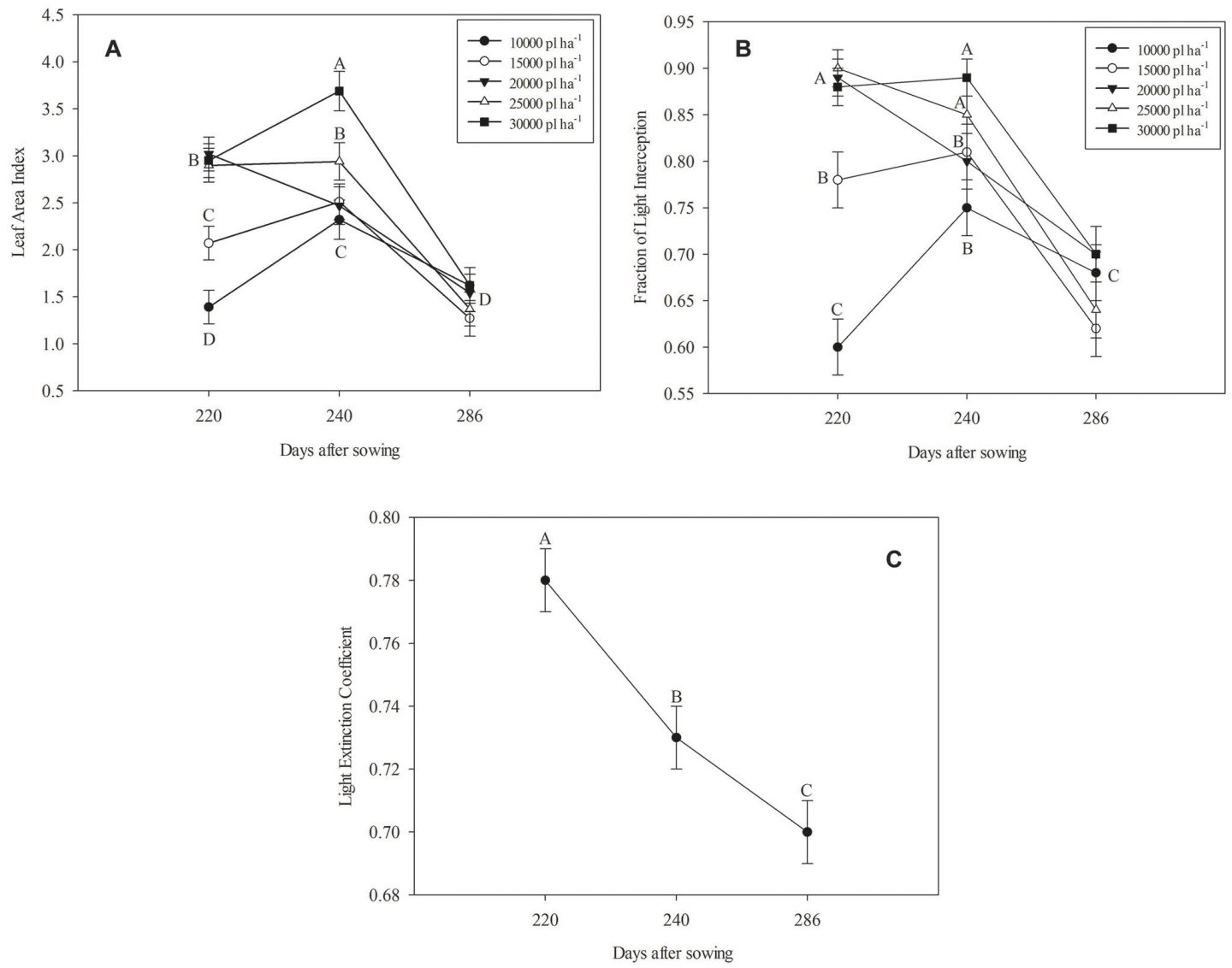

Figure 6. Canopy characteristics for arracacha (Arracacia xanthorrhiza Bancroft) plants of the Agrosavia La 22 variety, subjected to five population densities in four evaluation times. Cajamarca, Colombia. 2019. A. Leaf area index, B. Fraction of light interception, and C. Light extinction coefficient.

The data shown are the means of three replicates with the standard error indicated by the vertical lines. Different letters indicate significant differences for $\mathrm{p} \leq 0.05$, according to the DGC test. $\mathrm{pl} \mathrm{ha}^{-1}$ : plants per hectare.

Figura 6. Características del dosel de las plantas de arracacha (Arracacia xanthorrhiza Bancroft) de la variedad Agrosavia La 22 , sometidas a cinco densidades poblacionales en cuatro tiempos de evaluación. Cajamarca, Colombia. 2019. A. Índice de área foliar, B. Fracción de interceptación de la luz, y C. Coeficiente de extinción de luz.

Los datos mostrados son el promedio de tres repeticiones con el error estándar indicado por las líneas verticales. Diferentes letras indican diferencias significativas para $\mathrm{p} \leq 0,05$, según la prueba de la DGC. pl ha ${ }^{-1}$ : plantas por hectárea.

\section{Cracking index in the field and cracking index during harvest}

The cracking index in the field (CIf) and in harvest (CIh) presented significant differences by effect of the PD (Table 2). The CIf was significantly higher for the PD of 10,000 (0.24), and 15,000 (0.33) plants ha ${ }^{-1}$ compared to the other PDs that were statistically equal and their CIf ranged between 0.18 and 0.15 (Figure 7A). The CIh for the PD of 10,000 plants ha-1 (0.32) was significantly higher than the other PDs that showed a CIh between 0.26 and 0.17 (Figure 7B). 

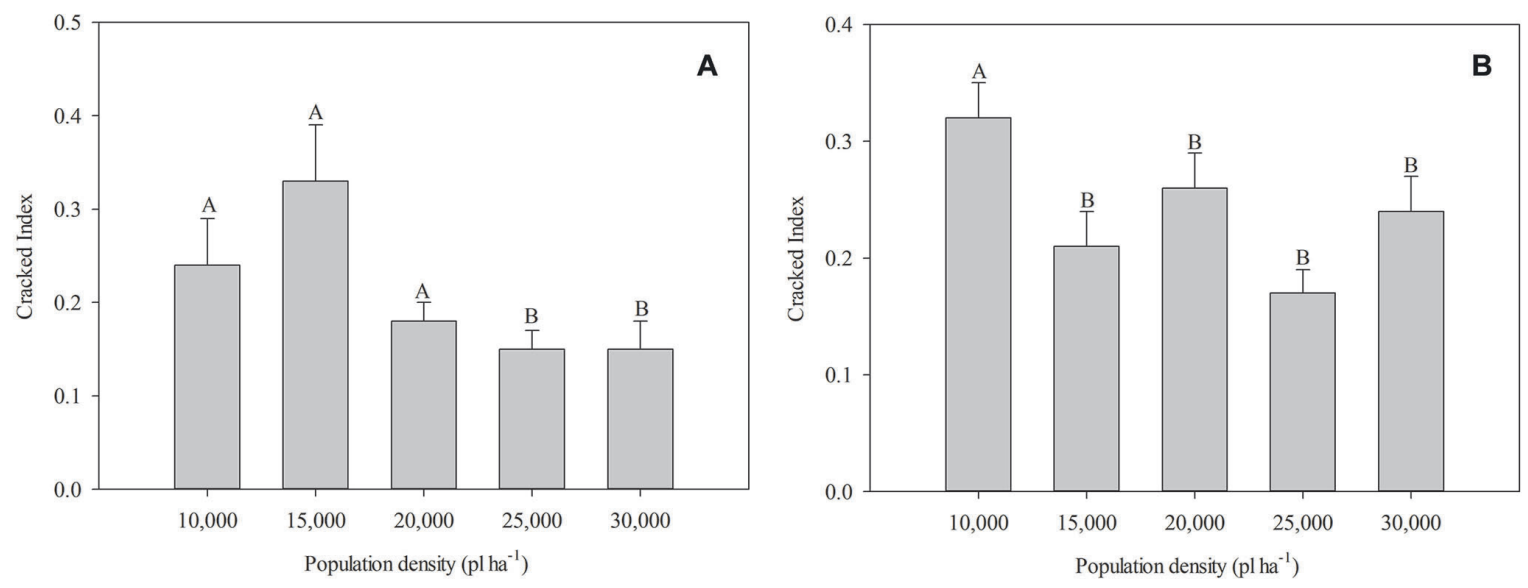

Figure 7. Cracking index for arracacha (Arracacia xanthorrhiza Bancroft) plants of the Agrosavia La 22 variety, subjected to five population densities. Cajamarca, Colombia. 2019.

A. Field cracking index, and B. Cracking index during harvest. The data shown are the means of three replicates with the standard error indicated by the vertical lines. Different letters indicate significant differences for $\mathrm{p} \leq 0.05$, according to the DGC test. $\mathrm{pl}$ ha ${ }^{-1}$ : plants per hectare.

Figura 7. Índice de agrietamiento de las plantas de arracacha (Arracacia xanthorrhiza Bancroft) de la variedad Agrosavia La 22 , sometidas a cinco densidades poblacionales. Cajamarca, Colombia. 2019.

A. Índice de agrietamiento en el campo, y B. Índice de agrietamiento durante la cosecha. Los datos mostrados son el promedio de tres repeticiones con el error estándar indicado por las líneas verticales. Diferentes letras indican diferencias significativas para p $\leq 0,05$, según la prueba de la DGC. pl ha ${ }^{-1}$ : plantas por hectárea.

\section{Characteristics of commercial roots}

All the characteristics of commercial roots showed significant differences between PDs, except for the average weight of commercial roots, which showed highly significant differences (Table 2). The characteristics of the commercial roots exhibited lower values with low PD (Table 3). The length, diameter, and average weight showed statistically equal values with PDs between 10,000 and 20,000 plants ha ${ }^{-1}$. With PDs higher than 20,000 plants ha-1, reductions in the length, diameter, and weight of commercial roots were observed (Table 3).

Table 3. Average characteristics of commercial roots of arracacha (Arracacia xanthorrhiza Bancroft) plants of the Agrosavia La 22 variety, subjected to five population densities. Cajamarca, Colombia. 2019.

Cuadro 3. Características promedio de raíces comerciales de arracacha (Arracacia xanthorrhiza Bancroft) de la variedad Agrosavia La 22, sometidas a cinco densidades poblacionales. Cajamarca, Colombia. 2019.

\begin{tabular}{ccccc}
\hline $\begin{array}{c}\text { Population density } \\
(\text { plants ha-1 })\end{array}$ & $\begin{array}{c}\text { Number of commercial } \\
\text { roots per plant }\end{array}$ & $\begin{array}{c}\text { Average commercial } \\
\text { root length }(\mathbf{c m})\end{array}$ & $\begin{array}{c}\text { Average diameter of } \\
\text { commercial root }(\mathbf{m m})\end{array}$ & $\begin{array}{c}\text { Average commercial } \\
\text { root weight }(\mathbf{g})\end{array}$ \\
\hline 10,000 & $12.08 \pm 0.86 \mathrm{~A}$ & $18.61 \pm 0.66 \mathrm{~A}$ & $57.49 \pm 1.23 \mathrm{~A}$ & $371.16 \pm 17.20 \mathrm{~A}$ \\
15,000 & $9.50 \pm 0.86 \mathrm{~B}$ & $17.50 \pm 0.66 \mathrm{~A}$ & $58.05 \pm 1.23 \mathrm{~A}$ & $362.40 \pm 21.26 \mathrm{~A}$ \\
20,000 & $8.83 \pm 0.86 \mathrm{~B}$ & $17.46 \pm 0.66 \mathrm{~A}$ & $57.20 \pm 1.23 \mathrm{~A}$ & $340.59 \pm 20.23 \mathrm{~A}$ \\
25,000 & $9.33 \pm 0.86 \mathrm{~B}$ & $15.58 \pm 0.66 \mathrm{~B}$ & $53.35 \pm 1.23 \mathrm{~B}$ & $269.30 \pm 14.71 \mathrm{~B}$ \\
30,000 & $7.25 \pm 0.86 \mathrm{~B}$ & $15.41 \pm 0.66 \mathrm{~B}$ & $54.14 \pm 1.23 \mathrm{~B}$ & $280.87 \pm 20.28 \mathrm{~B}$ \\
\hline
\end{tabular}

The data shown correspond to the average of three replicates. Different letters indicate significant statistical differences ( $\mathrm{p} \leq 0.05$ ) according to the DGC test. Figures after the \pm symbol indicate standard error. pl ha ${ }^{-1}$ : plants per hectare. / Los datos mostrados corresponden al promedio de tres repeticiones. Diferentes letras indican diferencias estadísticas significativas $(\mathrm{p} \leq 0,05)$ de acuerdo con la prueba de DGC. Cifras después del símbolo \pm indican el error estándar. pl ha ${ }^{-1}$ : plantas por hectárea. 


\section{Yield}

The commercial yield showed highly significant differences by effect of PD (Table 2). The lowest yield was found with the PD of 10,000 plants ha- $\left(25.91 \mathrm{t} \mathrm{ha}^{-1}\right)$ and the highest yields with the PDs of 30,000 (43.65 $\left.\mathrm{t} \mathrm{ha}^{-1}\right)$ and 25,000 plants ha- ${ }^{-1}\left(43.01 \mathrm{t} \mathrm{ha}^{-1}\right)$ (Figure 8A). A sigmoidal relationship $\left(\mathrm{r}^{2}=0.71\right)$ between PD and commercial yield was evident (Figure 8A). The yield curve stabilized with an PD of 22,000 plant ha ${ }^{-1}$, reaching a yield of 41.96 t ha ${ }^{-1}$. Hence, increasing the PD after 22,000 plants ha ${ }^{-1}$ did not generate a significant change in yield (Figure 8A).
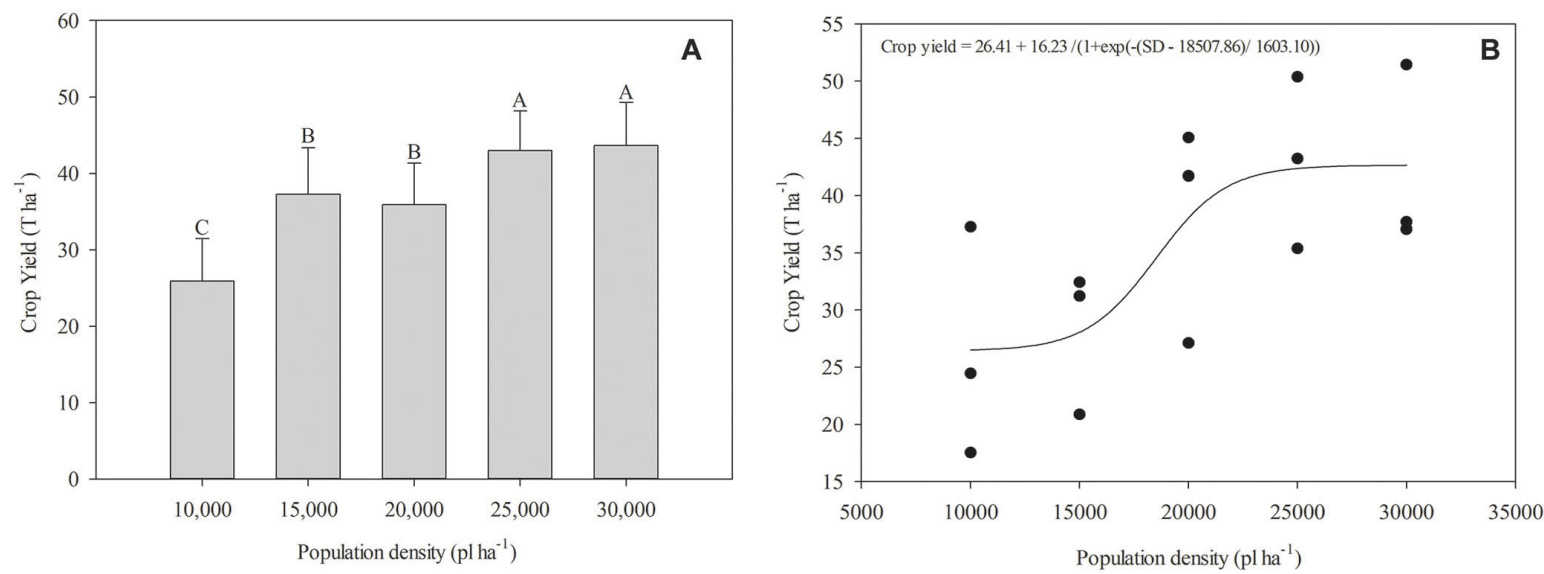

Figure 8. Commercial yield for arracacha (Arracacia xanthorrhiza Bancroft) plants of the Agrosavia La 22 variety, subjected to five population densities. Cajamarca, Colombia. 2019. A. Commercial yield, and B. Regression model for arracacha yield under different population densities.

The data shown are the means of three replicates with the standard error indicated by the vertical lines. Different letters indicate significant differences for $\mathrm{p} \leq 0.05$, according to the DGC test. $\mathrm{pl} \mathrm{ha}{ }^{-1}$ : plants per hectare.

Figura 8. Rendimiento comercial de las plantas de arracacha (Arracacia xanthorrhiza Bancroft) variedad Agrosavia La 22, sometidas a cinco densidades poblacionales. Cajamarca, Colombia. 2019. A. Rendimiento comercial, y B. Modelo de regresión para rendimiento de arracacha bajo diferentes densidades poblacionales.

Los datos mostrados son el promedio de tres repeticiones con el error estándar indicado por las líneas verticales. Diferentes letras indican diferencias significativas para $\mathrm{p} \leq 0,05$, de acuerdo con la prueba de DGC. $\mathrm{pl} \mathrm{ha}^{-1}$ : plantas por hectárea.

\section{Economic analysis}

An increasing trend was observed in total income, production costs, and profitability depending on the PD. The PDs of 25,000 and 30,000 plants ha ${ }^{-1}$ showed profitability of US\$16,215 and US\$ 16,091, respectively, being higher than the other PDs (Table. 4). Using the regression model for profitability based on PD $\left(\mathrm{r}^{2}=0.92\right)$, the curve stabilized with an PD of 22,222 plants ha ${ }^{-1}$, where a profitability of US\$15,333.06 was obtained (Figure 9). 
Table 4. Economic analysis of the productive system of arracacha (Arracacia xanthorrhiza Bancroft) plants of the Agrosavia La 22 variety, subjected to five population densities. Cajamarca, Colombia. 2019.

Cuadro 4. Análisis económico del sistema productivo de arracacha (Arracacia xanthorrhiza Bancroft) de la variedad Agrosavia La 22 , sometido a cinco densidades poblacionales. Cajamarca, Colombia. 2019.

\begin{tabular}{ccccc}
\hline $\begin{array}{c}\text { Population density } \\
\text { (plants ha-1) }^{-1}\end{array}$ & Total income (\$)* & Total costs $\mathbf{( \$ ) *}$ & Profitability $\mathbf{( \$ ) *}$ & $\begin{array}{c}\text { Monthly profitability } \\
(\$)^{*}\end{array}$ \\
\hline 10,000 & 13,575 & 4,785 & 8,789 & 732 \\
15,000 & 19,537 & 5,310 & 14,227 & 1,186 \\
20,000 & 18,824 & 5,669 & 13,155 & 1,096 \\
25,000 & 22,534 & 6,319 & 16,215 & 1,351 \\
30,000 & 22,869 & 6,778 & 16,091 & 1,341 \\
\hline
\end{tabular}

* Values in United States dollars (USD) with an average exchange rate for 2018 and 2019. pl ha ${ }^{-1}$ : plants per hectare. / * Valores en dólares estadounidenses (USD) con un promedio de tasa de cambio para el 2018 y 2019. pl ha' ${ }^{-1}$ : plantas por hectárea.

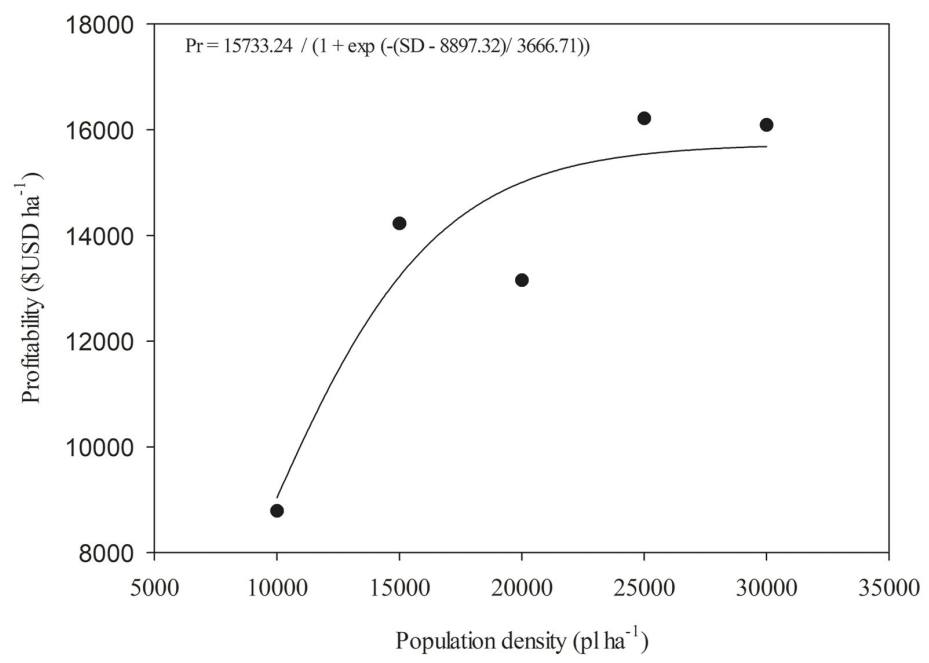

Figure 9. Profitability model for five population densities in arracacha (Arracacia xanthorrhiza Bancroft) plants of the Agrosavia La 22 variety. Cajamarca, Colombia. 2019.

The solid dots are the means of three replicates. The line is the trend curve developed using a third-order sigmoidal regression.

Figura 9. Modelo de rentabilidad para cinco densidades poblacionales en arracacha (Arracacia xanthorrhiza Bancroft) de la variedad Agrosavia La 22. Cajamarca, Colombia. 2019.

Los puntos sólidos son la media de tres réplicas. La línea es la curva de tendencia desarrollada usando una regresión sigmoidal de tercer orden.

\section{Discussion}

The current study showed the effect on the yield and economic indicators of five PDs and their relationship with leaf gas exchange and solar radiation interception processes. The PD is a decisive factor of crop yield (Liu et al., 2017). In arracacha there are few reports of the effect of PD on productivity (Graciano et al., 2007; Torales- 
Pacito et al., 2015; Zarate et al., 2009), documenting PDs higher than 60,000 plants ha ${ }^{-1}$. However, physiological processes such as solar radiation interception, leaf gas exchange, technical and economic viability associated with different PDs have not been studied.

In this research, the soil water potencial $\left(\Psi_{\mathrm{S}}\right)$ varied because of time and not of the PD (Figure 1), and the differences in time were related to changes in precipitation. The results contrast with those reported by BermúdezFlorez et al. (2018) and Honda et al. (2019), those who found that low PDs were related to high soil moisture due to low water consumption. This behavior can be attributed to the fact that arracacha adjusts the root growth based on intraspecific competition in such a way that root tissue area in the soil does not change according to PD. According to Silva et al. (2014), the observed $\Psi_{\mathrm{s}}$ values suggest good water availability since the soil was found between 66 $70 \%$ of the moisture of field capacity. This result suggests that arracacha plants were not subjected to water deficit. Hence, the variability of commercial yield was not generated by water deficit (Chaali et al., 2020).

In the current research, the relative chlorophyll content (RCC) was higher than 30 SPAD in all the PDs (Figure 2). In a similar plant such as carrot, an RCC higher than 30 SPAD was related to a nitrogen content higher than 1.6 $\%$ (Westerveld et al., 2004), being this leaf nitrogen content optimal for carrot (Hanlon \& Hochmuth, 2009). Hence, the increase in PD did not generate nitrogen deficiencies. This suggests that the functionality of the photosynthetic apparatus and enzymes involved in photosynthesis were not affected (Padilla et al., 2018). Nevertheless, the 20,000 plants ha-1 showed a high RCC, it indicated a better nitrogen status. The huge difference between 167 and 286 DAS could be generated by nitrogen remobilization (Kaur et al., 2015).

The leaf gas exchange (A) was evaluated from the beginning to the end of root filling. Because in arracacha this phenological stage is susceptible to water deficit (Chaali et al., 2020). The results showed that A was twofold (Figure 4A) and the yield was four times (Figure 8A) higher than the local variety of arracacha described by Jaimez et al. (2008). Thus, the Agrosavia La 22 variety has a higher yield potential due to its high photosynthetic capacity compared to genetic materials grown in Venezuela. This behavior observed in Agrosavia La 22 could be attributed to a better nitrogen use efficiency. This hypothesis should be addressed in future investigations.

High PDs can generate stress due to intraspecific competition and A measurement is a tool that can establish the degree of tolerance to these adverse conditions (Olechowicz et al., 2018). In this research, the PD did not affect A, and the observed differences are attributed to plant age (Figure 4A). This behavior was similar to the one reported by Jaimez et al. (2008). These reductions in A can be related to foliar senescence processes and the low demand for carbohydrates of the commercial root at this phenological stage. Because the peak of dry matter accumulation is between 150 and 240 DAS (mid-stage) (Chaali et al., 2020). Hence, the A may be downregulated by the sourcesink relationship at late stage ( $>240$ DAS). In Cassava, the competition for water between roots are given by a high PD to reduce leaf gas exchange (Silva et al., 2013). In this investigation, no water deficit was observed because of the PD; this explains the behavior evidenced in the leaf gas exchange process (Figure 4). Hence, the production of carbohydrates at leaf level used in growth processes and yield were not affected (Raines, 2011).

The leaf temperature variability indirectly estimates transpiration and gs, indicating water deficit (Biju et al., 2018) that could be generated by the effect of high PD (Bermúdez-Florez et al., 2018; Honda et al., 2019). The leaf temperature depression (LTD) did not show significant differences between PDs except for 240 DAS in the PD of 30,000 plants ha ${ }^{-1}$ (Figure 5A), and this was related to the water use efficiency (WUEi) (Figure 5C). This behavior was similar to what has been reported by Yang et al. (2014), where they found that the leaf temperature was the same with high or low PDs. The most negative LTD was observed at 240 DAS with 30,000 plants ha ${ }^{-1}\left(-1.4^{\circ} \mathrm{C}\right)$, which is a possible indicator of a moderate water deficit (Biju et al., 2018). However, this did not generate an effect in A (Figure 4A) and PRI (Figure 5B), which reflects the light use efficiency that is related to the photochemical efficiency of PSII (Castro \& Sanchez-Azofeifa, 2018). In this sense, the high PD in arracacha did not generate a 
water deficit that affected the functionality and activity of the photosynthetic apparatus similar to what was reported by Olechowicz et al. (2018) in potato.

In the present research, the LAI was influence by PD but the light distribution in the canopy did not change by PD effect. Similar to what was reported by Quevedo et al. (2018), this suggests that it is a feature closely associated with the genotype. The observed k (Figure 6C) was typical of plants with planofile leaves (Wang et al., 2007), where the highest radiation uptake occurs in the upper third of the canopy. Nevertheless, during the maximum root filling (240 DAS), the PDs of 25,000 and 30,000 plants ha ${ }^{-1}$ showed a higher LAI and a Fi higher than 0.85 (Figure 6A-B). Further, it is possible that crop photosynthesis increased (Richards, 2000). What generates a more significant accumulation of carbohydrates destined for root storage that consequently gives a high yield (Jaimez et al., 2008). Hence, the LAI and Fi explain the high yield observed in the PDs of 25,000 and 30,000 plants haHowever, these PDs reduce the number and size of the commercial root (Table 3), decreasing the yield per plant, similar to what Torales-Pacito et al. (2015) founds in arracacha and other root crop as Yacon (Doo et al., 2001). These changes in the yield components and the root size are due to intraspecific competition given by a high PD that affects growth so that the distribution of carbohydrates to the root is limited (Silva et al., 2013; Testa et al., 2016). Nonetheless, the yield is compensated by harvesting more plants (Hashemi et al., 2005). The direct relationship found between yield and PD (Figure 9B) has been previously described by Torales-Pacito et al. (2015) and Zarate et al. (2009). However, the performance data obtained with the best PD was 2.5-fold higher than what was reported by Torales-Pacito et al. (2015) and 4-fold higher than what Zarate et al. (2009) founds.

In the current study, the inflection point of yield was a PD of 22,000 plants ha ${ }^{-1}$ This means that the increase in the PD from 22,000 plants ha ${ }^{-1}$ onwards did not generate a significant increase in yield but using PD higher than 30,000 plants ha $^{-1}$ could reduce yield. According to Torales-Pacito et al. (2015), this occurs because the commercial root yield of arracacha was reduced by decreasing the distance between plants less than $0.25 \mathrm{~m}$.

Root cracking generates significant yield losses (Hartz et al., 2005). The CIf was reduced with the use of PD higher than 20,000 plants ha-1 (Figure 7A) because, with this PD, the commercial root reaches a small size, which makes it less susceptible to cracking (Table. 3). On the contrary, plants with larger roots such as those observed with low PDs are more susceptible to cracking. In commercial roots such as carrots, the quality is also measured through broken roots at harvest and healed wounds, which should not exceed $7 \%$ for commercial acceptance (RichmondZumbado \& Méndez-Soto, 2010). In the present research, the cracking index in PD higher than 20,000 plants ha-1 was near to $7 \%$. Nevertheless, the optimum cracking index for arracacha should be estimated in future research.

New agricultural management practices must be technically and economically viable (Zhang et al., 2018). By increasing the PD, an increase in the profitability of the production system was generated (Table 4), obtaining the best profitability (US\$15,333.06) with 22,222 plants ha-1 (Figure 9). This behavior was similar to the one described by Torales-Pacito et al. (2015), who affirm that using a high PD, the profitability reaches US\$19,227.37. The average profitability of arracacha for Colombia between the years 2006-2010 was US\$ 3,184.25 (GutiérrezMalaxechebarría, 2011) in contrast to what this study obtained. Therefore, an increase of US\$12,148.81 in production system profitability was generated using the optimal PD $\left(22,222\right.$ plant ha $\left.{ }^{-1}\right)$. The production cost increase with population density. Due to seed and harvest costs (Table 4). With optimal PD $\left(22,222\right.$ plant ha $\left.^{-1}\right)$, the yield and production cost increase by $61.94 \%$ and $17.56 \%$, respectively, compared to $10,000 \mathrm{plant} \mathrm{ha}^{-1}$. It generates this high benefit-cost ratio. In annual crops such as corn and rice-wheat cropping system, high population densities have shown the best yields, profit margin, and optimal benefit-cost ratio for the farmer (Quevedo et al., 2018; Singh et al., 2020). 


\section{Conclusions}

High population densities in A. xanthorrhiza plants did not generate water or nutritional limitations that affect the photosynthetic process. However, with high population densities increases the photosynthetically active radiation (PAR) interception and possibly increases crop photosynthesis allowing a greater accumulation and breakdown of carbohydrates towards the tuberous root. Therefore, yield increased as a function of population density.

In the population density of 22,222 plants $\mathrm{ha}^{-1}(1 \mathrm{~m} \mathrm{x} 0.45 \mathrm{~m})$, the Agrosavia La 22 variety reaches a yield of $41.96 \mathrm{t} \mathrm{ha}^{-1}$. This PD shows the lowest cracking index at field and harvest due to having roots with less length, diameter, and weight. The profitability with this PD for the productive chain of \$15333.06 USD. Nevertheless, the process validation of this practice to a commercial scale is necessary.

\section{Acknowledgments}

The authors want to acknowledge the Corporacion Colombiana de Investigacion Agropecuaria - AGROSAVIA and Ministerio de Agricultura y Desarrollo Rural of Colombia who funding this research. This study is a part of the Project "Integrated crop management focused on soils, water and weed control for the production of arracacha in Colombia" included in the macro project "Generation and use of genetic materials, integrated crop management, postharvest and transformation of arracacha in the Andean region of Colombia."

\section{References}

Alvarado, A., \& Ochoa, L. (2010). Tecnologías locales de producción de arracacha (Arracacia xanthorrhiza Bancroft) en el municipio de Boyacá, departamento de Boyacá. Revista U.D.C.A. Actualidad \& Divulgación Científica, 13(1),125133. https://doi.org/10.31910/rudca.v13.n1.2010.716

Al-Naggar, A. M., Shabana, R. A., Atta, M. M., \& Al-Khalil, T. H. (2015). Maize response to elevated plant density combined with lowered N-fertilizer rate is genotype-dependent. The Crop Journal, 3(2), 96-109. https://doi.org/10.1016/j. cj.2015.01.002

Bänziger, M., Edmeades, G. O., \& Lafitte, H. R. (1999). Selection for drought tolerance increases maize yields across a range of nitrogen levels. Crop Science, 39(4),1035-1040. https://doi.org/10.2135/cropsci1999.0011183X003900040012x

Bermúdez-Florez, L. N., Cartagena-Valenzuela, J. R., \& Ramírez-Builes, V.H. (2018). Soil humidity and evapotranspiration under three coffee (Coffea arabica L.) planting densities at Naranjal experimental station (Chinchiná, Caldas, Colombia). Acta Agronómica, 67(3),402-413. https://doi.org/10.15446/acag.v67n3.67377

Biju, S., Fuentes, S., \& Gupta, D. (2018). The use of infrared thermal imaging as a non-destructive screening tool for identifying drought-tolerant lentil genotypes. Plant Physiology and Biochemistry, 127,11-24. https://doi.org/10.1016/j. plaphy.2018.03.005

Bréda, N. J. (2008). Leaf area index. In S. E. Jørgensen, \& B. D. Fath (Eds.), Encyclopedia of Ecology (pp. 2148-2154). Academic Press. https://doi.org/10.1016/B978-008045405-4.00849-1

Castro, S., \& Sanchez-Azofeifa, A. (2018). Testing of automated photochemical reflectance index sensors as proxy measurements of light use efficiency in an aspen forest. Sensors, 18(10), Article 3302. https://doi.org/10.3390/s18103302 
Chaali, N., Ouazaa, S., Jaramillo-Barrios, C. I., Araujo Carrillo, G. A., \& Ávila Pedraza, E. Á. (2020). Edaphoclimatic characterization and crop water requirement of Arracacha (Arracacia xanthorrhiza Bancroft) roots in upland production areas. Scientia Horticulturae, 272, Article 109533. https://doi.org/10.1016/j.scienta.2020.109533

Chastain, D. R., Snider, J. L., Choinski, J. S., Collins, G. D., Perry, C.D., Thimoty, J.W., Ronald, G., Byrd, S.A., \& Porter, W. (2016). Leaf ontogeny strongly influences photosynthetic tolerance to drought and high temperature in Gossypium hirsutum. Journal of Plant Physiology, 199, 18-28. https://doi.org/10.1016/j.jplph.2016.05.003

Departamento Administrativo Nacional de Estadística. (2020). Sistema de información de precios SIPSA, $2018-2019$. Recuperado en marzo, 2020, de https://www.dane.gov.co/index.php/estadisticas-por-tema/agropecuario/sistema-deinformacion-de-precios-sipsa

Drake, J. E., Power, S. A., Duursma, R. A., Medlyn, B. E., Aspinwall, M. J., Choat, B., Creek, D., Eamus, D., Maier, C., Pfautsch, S., Smith, R.A., \& Tjoelker, D.T. (2017). Stomatal and non-stomatal limitations of photosynthesis for four tree species under drought: A comparison of model formulations. Agricultural and Forest Meteorology, 247, 454-466. https://doi.org/10.1016/j.agrformet.2017.08.026

Doo, H. S., Ryu, J. H., Lee, K. S., \& Choi, S. Y. (2001). Effect of plant density on growth responses and yield in yacon. Korean Journal of Crop Science, 46(5), 407-410.

Fang, H., \& Liang, S. (2008). Leaf area index models. In S. E. Jørgensen, \& B. D. Fath (Eds.), Encyclopedia of Ecology (pp. 2139-2148). Elsevier B. V. https://doi.org/10.1016/B978-0-12-409548-9.09076-X

Flénet, F., Kiniry, J. R., Board, J. E., Westgate, M. E., \& Reicosky, D. C. (1996). Row spacing effects on light extinction coefficients of corn, sorghum, soybean, and sunflower. Agronomy Journal, 88(2), 185-190. https://doi.org/10.2134/ agronj1996.00021962008800020011x

Garbulsky, M. F., Peñuelas, J., Papale, D., \& Filella, I. (2008). Remote estimation of carbon dioxide uptake by a Mediterranean forest. Global Change Biology, 14(12), 2860-2867. https://doi.org/10.1111/j.1365-2486.2008.01684.x

García, J., \& Moreno, L. P. (2016). Respuestas fisiológicas de Theobroma cacao L. en etapa de vivero a la disponibilidad de agua en el suelo. Acta Agronómica, 65(1), 44-50. https://doi.org/10.15446/acag.v65n1.48161

Garnica-Montaña, J. P., Rodriguez, O. J., Jaramillo-Barrios, C. I., \& Vallejo-Cabrera, F. A. (2020). Diversidad morfológica y caracteres de selección del germoplasma de arracacha (Arracacia xanthorriza Bancr.) en Colombia. Ciencia y Agricultura, 17(3), 49-62. https://doi.org/10.19053/01228420.v17.n3.2020.11150

Graciano, J. D., Zárate, N. A., Vieira, M. do C., Rosa, Y. B., \& M. A. Sediyama. (2007). Espaçamento entre fileiras e entre plantas na produção da mandioquinha-salsa 'Branca'. Ciência e Agrotecnologia, 31(6), 1688-1695. https://doi. org/10.1590/S1413-70542007000600013

Gutiérrez-Malaxechebarría, Á. M. (2011). Nueva aparcería en la producción de arracacha (Arracacia xanthorrhiza) en Cajamarca (Colombia). Cuadernos de Desarrollo Rural, 8(67), 205-228. https://doi.org/10.11144/Javeriana.cdr8-67.napa

Hanlon, E. A., \& Hochmuth, G. J. (2009). Carrot. In C. R. Campbell (Ed.), Reference sufficiency ranges for plant analysis in the southern region of the United States (pp. 63-65). Southern Region Agricultural Experiment Station.

Hartz, T. K., Johnstone, P. R., \& Nunez, J. J. (2005). Production environment nitrogen fertility affect carrot cracking. HortScience, 40(3), 611-615. https://doi.org/10.21273/hortsci.40.3.611 
Hashemi, A. M., Herbert, S. J., \& Putnam, D. H. (2005). Yield response of corn to crowding stress. Agronomy Journal, 97(3), 839-846. https://doi.org/10.2134/agronj2003.0241

Hatfield, J. L., \& Dold, C. (2019). Water-use efficiency: advances and challenges in a changing climate. Frontiers in Plant Science, 10, Article 103. https://doi.org/10.3389/fpls.2019.00103

Hermann, M. (1997). Arracacha (Arracaccia xanthorrhiza Bancroft). In M. Hermann, \& J. Heller (Eds.), Andean Roots and Tubers: Ahipa, arracacha, maca and yacon (pp. 75-172). Plant Genetics Resources Institute.

Honda, E. A., Pilon, N. A. L., \& Durigan, G. (2019). The relationship between plant density and survival to water stress in seedlings of a legume tree. Acta Botanica Brasilica, 33(3), 602-606. https://doi.org/10.1590/0102-33062018abb0432

Hou, W., Rizwan, M., Zhang, J., Lu, J., Ren, T., Cong, R., \& Li, X. (2019). Nitrogen rate and plant density interaction enhances radiation interception, yield and nitrogen use efficiency of mechanically transplanted rice. Agriculture, Ecosystems and Environment, 269, 183-192. https://doi.org/10.1016/j.agee.2018.10.001

Imai, K., Suzuki, Y., Mae, T., \& Makino, A. (2008). Changes in the synthesis of Rubisco in rice leaves in relation to senescence and N influx. Annals of Botany, 101(1), 135-144. https://doi.org/10.1093/aob/mcm270

Jaimez, R. E., Santos, N., Añez, B., Vásquez, J., \& Espinoza, W. (2008). Photosynthesis of field-grown Arracacha (Arracacia xanthorriza Bancroft) cultivars in relation to root-yield. Scientia Horticulturae, 118(2), 100-105. https://doi. org/10.1016/j.scienta.2008.05.027

Jaramillo-Barrios, C. I., Barragán-Quijano, E., \& Monje-Andrade, B. (2019). Populations of Spodoptera frugiperda (Lepidoptera: Noctuidae) cause significant damage to genetically modified corn crops. Revista Facultad Nacional de Agronomía Medellín, 72(3), 8953-8962. https://doi.org/10.15446/rfnam.v72n3.75730

Kohzuma, K., \& Hikosaka, K. (2018). Physiological validation of photochemical reflectance index (PRI) as a photosynthetic parameter using Arabidopsis thaliana mutants. Biochemical and Biophysical Research Communications, 498(1), 52-57. https://doi.org/10.1016/j.bbrc.2018.02.192

Kováč, D., Veselovská, P., Klem, K., Večeřová, K., Ač, A., Peñuelas, J., \& Urban, O. (2018). Potential of Photochemical Reflectance Index for indicating photochemistry and light use efficiency in leaves of european beech and Norway spruce trees. Remote Sensing, 10(8), Article 1202. https://doi.org/10.3390/rs10081202

Kaur, G., Asthir, B., Bains, N. S., \& Farooq, M. (2015). Nitrogen nutrition, its assimilation and remobilization in diverse wheat genotypes. International Journal of Agriculture and Biology, 17(3), 1814-9596. https://doi.org/10.17957/ $\mathrm{IJAB} / 17.3 .14 .539$

Liu, Q., Zhou, X., Li, J., \& Xin, C. (2017). Effects of seedling age and cultivation density on agronomic characteristics and grain yield of mechanically transplanted rice. Scientific Reports, 7(1),14072. https://doi.org/10.1038/s41598-017-14672-7

Luo, L. P., Yu, Z. W., Wang, D., Zhang, Y. L., \& Shi, Y. (2011). Effects of plant density and soil moisture on photosynthetic characteristics of flag leaf and accumulation and distribution of dry matter in wheat. Acta Agronomica Sinica, 37(6), 1049-1059. https://doi.org/10.1016/S1875-2780(11)60030-8

Magolbo, L. A., Carmo, E. L., Garcia, E. L., Fernandes, A. M., \& Leonel, M. (2015). Dry matter accumulation and mineral nutrition of arracacha in response to nitrogen fertilization. Pesquisa Agropecuária Brasileira, 50(8), 669-680. https:// doi.org/10.1590/S0100-204X2015000800005

Morillo, E., Madeira, N., \& Jaimez, R. (2020). Arracacha. In E. Geoffriau \& P. W. Simon (Eds.), Carrots and related vegetable Umbelliferae (2nd ed., p. 346). CAB International. https://doi.org/10.1079/9781789240955.0000 ISSN 2215-3608 doi:10.15517/am.v32i2.43281 
Madeira, N. R., Ferreira de Carvalho, A. D., da Silva, G. O., Borges Pinheiro, J., Borges Pereira, R., Michereff Filho, M., Pires Feldberg, N., Moreira, S. O., Ribeiro Silveira, G. S., \& Cássia, R. M. (2017). Proposição de um sistema de produção de mudas de mandioquinha-salsa (Circular Técnica 161). Brazilian Agricultural Research Corporation.

Olechowicz, J., Chomontowski, C., Olechowicz, P., Pietkiewicz, S., Jajoo, A., \& Kalaji, M. H. (2018). Impact of intraspecific competition on photosynthetic apparatus efficiency in potato (Solanum tuberosum) plants. Photosynthetica, 56(3), 971-975. https://doi.org/10.1007/s11099-017-0728-x

Padilla, F. M., Gallardo, M., Peña-Fleitas, M. T., De Souza, R., \& Thompson, R.B. (2018). Proximal optical sensors for nitrogen management of vegetable crops: A review. Sensors, 18(7), 2083. https://doi.org/10.3390/s18072083

Page, K. L., Dang, Y. P., Dalal, R.C., Reeves, S., Thomas, G., Wang, W., \& Thompson, J.P. 2019. Changes in soil water storage with no-tillage and crop residue retention on a Vertisol: Impact on productivity and profitability over a 50 year period. Soil Tillage Research, 194, Article 104319. https://doi.org/10.1016/j.still.2019.104319

Pinto-Acero, Y. L., Alvarado-Gaona, Á. E., Burgos-Ávila, Y. E., Balaguera-López, H. E., \& Ramírez-González, S. I. (2019). Characterization of three Arracacia xanthorrhiza Bancroft genotypes using morphological and color parameters. Revista Colombiana de Ciencias Hortícolas, 13(3), 426-434. https://doi.org/10.17584/rcch.2019v13i3.8948

Quevedo, Y. M., Beltrán, J. I., \& Barragán-Quijano, E. (2018). Effect of sowing density on yield and profitability of a hybrid corn under tropical conditions. Agronomía Colombiana, 36(3), 248-256. https://doi.org/10.15446/agron.colomb. v36n3.71268

Raines, C. A. (2011). Increasing photosynthetic carbon assimilation in C3 plants to improve crop yield: current and future strategies. Plant Physiology, 115(1), 36-42. https://doi.org/10.1104/pp.110.168559

Richards, R. A. (2000). Selectable traits to increase crop photosynthesis and yield of grain crops. Journal of Experimental Botany, 51(1), 447-458. https://doi.org/10.1093/jexbot/51.suppl_1.447

Richmond-Zumbado, F., \& Méndez-Soto, C. (2010). Rendimiento de 12 híbridos comerciales de zanahoria (Daucus carota L.) en el campo y en la planta de empaque. Agronomía Mesoamericana, 21(1), 167-176. https://doi.org/10.15517/ am.v21i1.4922

Rodríguez, O. J., Garnica, J. P., Villamil, J. E., Atencio, L. A., \& Martínez, R.A. (2019). AGROSAVIA La 22: Primera variedad de arracacha en Colombia: Amarilla, de alta producción y adaptada a condiciones agroecológicas de la zona Andina. Corporación Colombiana de Investigación Agropecuaria.

Rosso, C. A., Medina, C. I., \& Lobo, M. (2002). Morphologic characterization and agronomic evaluation of a Colombian collection of arracacha (Arracacia xanthorrhiza Bancroft). Plant Genetic Resources Newsletter, 132, 22-29.

Sher, A., Khan, A., Ashraf, U., Liu, H. H., \& Li, J. C. (2018). Characterization of the effect of increased plant density on canopy morphology and stalk lodging risk. Frontiers Plant Science, 11(9), Article 1047. https://doi.org/10.3389/ fpls.2018.01047

Shi, D. Y., Li Y. H., Zhang, J., Liu, P., Zhao, B., \& Dong, S. (2016). Increased plant density and reduced N rate lead to more grain yield and higher resource utilization in summer maize. Journal of Integrative Agriculture, 15(11), 2515-2528. https://doi.org/10.1016/S2095-3119(16)61355-2

Silva, B. M., da Silva, É. A., de Oliveira, G.C., Ferreira, M. M., \& Serafim, M. E. (2014). Plant-available soil water capacity: estimation methods and implications. Revista Brasilera de Ciência do Solo, 38(2), 464-475. https://doi.org/10.1590/ s0100-06832014000200011 
Silva, T. S., Lima e Silva, P. S., Braga, J. D., Da Silveira, L. M., \& De Sous, P. P. (2013). Planting density and yield of cassava roots. Revista Ciência Agronômica, 44(2), 317-324. https://doi.org/10.1590/S1806-66902013000200014

Singh, M., Kumar, P., Kumar, V., Solanki, I. S., McDonalda, A. J., Kumar, A., Pooniaa, S. P., Kumar, V., Ajay, A., Kumar, A., Singh, D. K., Balwinder-Singha, Singh, S., \& Malik, R. K. (2020). Intercomparison of crop establishment methods for improving yield and profitability in the rice-wheat system of Eastern India. Field Crops Research, 250, Article 107776. https://doi.org/10.1016/j.fcr.2020.107776

Slattery, R. A., Vanloocke, A., Bernacchi, C. J., Zhu, X. G., \& Ort, D.R. (2017). Photosynthesis, light use efficiency, and yield of reduced-chlorophyll soybean mutants in field conditions. Frontiers in Plant Science, 18(8), Article 549. https://doi. org/10.3389/fpls.2017.00549

Son, J. K., Shin, W. T., \& Cho, J. Y. (2017). Laboratory and field assessment of the Decagon 5TE and GS3 sensors for estimating soil water content in saline-alkali reclaimed soils. Communications in Soil Science and Plant Analysis, 48(19), 2268-2279. https://doi.org/10.1080/00103624.2017.1411501

Song, D., Tariq, A., Pan, K., Khan, S.U., Saleh, T. A., Gong, S., Zhang, A., \& Wu, X. (2020). Influence of planting distance and density on the yield and photosynthetic traits of sweet potato (Ipomoea balatas L.) under an intercropping system with walnut (Juglans regia) saplings. Soil Tillage Research, 196, Article 104484-. https://doi.org/10.1016/j. still.2019.104484

Sun, D., Zhang, W., Lin, Y., Liu, Z., Shen, W., Zhou, L., Rao, X., Liu, S., Cai, X., He, D., \& Fu, S. (2018). Soil erosion and water retention varies with plantation type and age. Forest Ecology Management, 422, 1-10. https://doi.org/10.1016/j. foreco.2018.03.048

Testa, G., Reyneri, A., \& Blandino, M. (2016). Maize grain yield enhancement through high plant density cultivation with different inter-row and intra-row spacings. European Journal of Agronomy, 72, 28-37. https://doi.org/10.1016/j. eja.2015.09.006

Torales-Pacito, E. P., Zárate, N. A. H., Vieira, M. D. C., Menani-Heid, D., Bassi-Moreno, L., \& Rotermel-Grando, V. (2015). Productivity peruvian carrot in response to plant spacings and average masses of seedlings. Bioscience Journal, 31(2), 433-444.

Vahrmeijer, J. T., Annandale, J. G., Steyn, J. M., \& Bristow, K. L. (2018). Model parameters of four important vegetable crops for improved water use and yield estimation. Water S.A, 44(4), 528-538. https://doi.org/10.4314/wsa.v44i4.02

Vongcharoen, K., Santanoo, S., Banterng, P., Jogloy, S., Vorasoot, N., \& Theerakulpisut, P. (2018). Seasonal variation in photosynthesis performance of cassava at two different growth stages under irrigated and rain-fed conditions in a tropical savanna climate. Photosynthetica, 56, 1398-1413. https://doi.org/10.1007/s11099-018-0849-x

Wang, W. M., Li, Z. L., \& Su, H. B. (2007). Comparison of leaf angle distribution functions: Effects on extinction coefficient and fraction of sunlit foliage. Agricultural and Forest Meteorology, 143(1-2), 106-122. https://doi.org/10.1016/j. agrformet.2006.12.003

Westerveld, S. M., McKeown, A. W., Scott-Dupree, C. D., \& McDonald, M. R. (2004). Assessment of chlorophyll and nitrate meters as field tissue nitrogen tests for cabbage, onions, and carrots. Horttechnology, 14(2), 176-188. https://doi. org/10.21273/horttech.14.2.0179

Yang, G, Z., Luo, X. J., Nie, Y. C., \& Zhang, X. (2014). Effects of plant density on yield and canopy micro environment in hybrid cotton. Journal Integrative Agriculture, 13(10), 2154-2163. https://doi.org/10.1016/S2095-3119(13)60727-3 
Zarate, N. A. H., Vieira, M. D. C., Graciano, J. D., Gonzales-Figueiredo, P., Brandão-Blans, N., \& Mazaron-Curioni, B. (2009). Produtividade de mandioquinha-salsa sob diferentes densidades de plantio e tamanho das mudas. Ciência e Agrotecnologia, 33(1), 139-143. https://doi.org/10.1590/S1413-70542009000100020

Zarate, N. A. H., Vieira, M. D. C., Rech, J., Quast, A., Pontim, B. C., \& Gassi, R. P. (2008). Yield and gross income arracacha in monocrop and intercropping with Japanese bunching onion and parsley. Horticultura Brasileira, 26(2), $287-291$. https://doi.org/10.1590/s0102-05362008000200032

Zhang, H., Yu, C., Kong, X., Hou, D., Gu, J., Liu, L., Wang, Z., \& Yang, J. (2018). Progressive integrative crop managements increase grain yield, nitrogen use efficiency and irrigation water productivity in rice. Field Crops Research, $215,1-11$. https://doi.org/10.1016/j.fcr.2017.09.034 